\title{
THE NON-SPORING ANAEROBIC BACTERIA IN HUMAN FAECES
}

\author{
Susan Peach, Fresia Fernandez, Katherine Johnson \\ AND B. S. DRASAR \\ Department of Bacteriology, Wright-Fleming Institute, St Mary's Hospital Medical School, \\ London W2 $1 P G$
}

DiET has long been assumed to be one of the major determinants of the faecal flora (Dudgeon, 1926). Studies with experimental animals provide support for this hypothesis (Smith, 1965); however, studies with human faeces have provided less satisfactory evidence (Moore, Cato and Holdeman 1969).

In a study of faecal specimens from different dietary groups in various parts of the world, we demonstrated differences in the numbers of bacteroides organisms present in faeces (Hill et al., 1971). In the present paper we report on the more detailed classification of the non-sporing anaerobes isolated in that study and during subsequent extensions of the study.

\section{MATERIALS AND METHODS}

Source of faeces. Stool samples were obtained from groups of people consuming a mixed western diet, in England, Scotland and the USA, and from people living on diets with a high carbohydrate content in India, Uganda and Japan. The characteristics of these groups are shown in table I. The groups contained both men and women. All were healthy individuals, mostly aged between 20 and 50. Samples from the USA came from both black and white persons.

Transport and storage of specimens. Fresh samples of faeces were diluted 1 in 10 in 10\% glycerol broth and immediately frozen in solid carbon dioxide or in liquid nitrogen for transport to London (Crowther, 1971). The samples were stored at $-50^{\circ} \mathrm{C}$.

Isolation of non-sporing anaerobic bacteria. Isolation plates were seeded in an anaerobic cabinet. During the initial stages of this investigation a rigid Perspex cabinet filled with oxygen-free nitrogen $\left(\mathrm{N}_{2}\right)$ containing $5 \%$ carbon dioxide $\left(\mathrm{CO}_{2}\right)$ was employed (Drasar, 1967). Later studies were carried out in a flexible polyvinyl cabinet filled with $5 \% \mathbf{C O}_{2}$ in a mixture of $90 \% \mathrm{~N}_{2}$ and $10 \%$ hydrogen $\left(\mathrm{H}_{2}\right)$ (Aranki et al., 1969). Ten-fold dilutions of the specimens were prepared in Brain-Heart-Infusion (BHI) broth (Oxoid) containing $0.05 \%(\mathrm{w} / \mathrm{v})$ cysteine hydrochloride and $0.03 \%$ sodium formaldehyde sulphoxylate as reducing agents. The diluent was heated to $100^{\circ} \mathrm{C}$ before being introduced into the cabinet, where it was dispensed and allowed to cool in the anaerobic environment.

$0 \cdot 1-\mathrm{ml}$ samples of appropriate dilutions were spread on the surface of plates of Reinforced Clostridial Medium (Oxoid) with $1 \%$ glucose (w/v), $1 \%$ liver digest (Panmede, Paines and Byrne, Greenford, England) and 10\% defibrinated horse blood. In order to maintain the media in a reduced state, the plates were poured and dried in the Perspex cabinet, or stored for 3 days in the flexible cabinet.

Seeded plates were packed into anaerobic jars and on removal from the cabinet the jars were re-evacuated and filled with a gas mixture containing $30 \% \mathrm{CO}_{2}$ and $70 \% \mathrm{H}_{2}$ and incubated at $37^{\circ} \mathrm{C}$ for 3 days. Cold " $\mathrm{D}$ " catalyst was used in the anaerobic jars (Englhard Industries, Cindeford, Gloucestershire).

Received 13 July 1973; accepted 23 Aug. 1973

J. MED. MICROBIOL.-VOL. 7 (1974) 
Preservation of cultures. Ten colonies were picked from the isolation plates and subcultured into Robertson's cooked meat medium. After incubation for 3 days, the cultures were checked for purity and aerobic growth. Glycerol was then added to a final concentration of $10 \%(\mathrm{v} / \mathrm{v})$ and the stock cultures were stored at $-50^{\circ} \mathrm{C}$.

\section{Identification of isolates}

The isolates were placed into various broad groups on the basis of their appearance in a Gram-stained preparation (Preston and Morrell, 1962) and on the detection of the end-products of glucose metabolism by gas-liquid chromatography. They were assigned to species on the basis of their biochemical reactions.

TABLE I

Populations studied

\begin{tabular}{|c|c|c|c|}
\hline Diet & Population & $\begin{array}{l}\text { Number of } \\
\text { samples }\end{array}$ & $\begin{array}{l}\text { Number of } \\
\text { isolates }\end{array}$ \\
\hline $\begin{array}{l}\text { Normal mixed western, high } \\
\text { fat* } \\
\text { Normal mixed western, high } \\
\text { fat* } \\
\text { Normal mixed western, high } \\
\text { fat* } \\
\text { Rice diet, high carbohydrate* } \\
\text { Matoke (boiled mashed } \\
\text { bananas), high carbo- } \\
\text { hydrate } \\
\text { Fruits and vegetables, high } \\
\text { carbohydrate }\end{array}$ & $\begin{array}{l}\text { England; staff and students, St Mary's } \\
\text { Hospital Medical School, London } \\
\text { Scotland; staff and students, Edinburgh } \\
\text { University Medical School } \\
\text { USA; staff members, Center for Disease } \\
\text { Control, Atlanta, Georgia } \\
\text { India; villagers, Vellore, S. India; } \\
\text { controls in a study of tropical sprue } \\
\text { Uganda; villagers, Kyandondo region; } \\
\text { parents accompanying children to } \\
\text { Kwashiorkor Clinic } \\
\text { Japan; villagers, Yonga; mostly farmers } \\
\text { or housewives }\end{array}$ & $\begin{array}{l}33 \\
17\end{array}$ & $\begin{array}{r}116 \\
37\end{array}$ \\
\hline
\end{tabular}

* The commonly used terms "high fat" and " high carbohydrate" applied to diets denote " rich in fat" and "rich in carbohydrate" respectively.

\section{Gas-liquid chromatography}

Preparation of the sample. A 4-ml volume of a 3-day culture in $1 \%$ glucose broth (Cato et al., 1970) was acidified with $0.5 \mathrm{ml}$ of $50 \%$ aqueous sulphuric acid and extracted with $4 \mathrm{ml}$ of diethyl ether. After centrifugation to break the emulsion, the ether layer was pipetted off and dried over magnesium sulphate. Reference solutions were prepared as described by Cato et al. (1970). Controls were of uninoculated glucose broth. Pyruvic, lactic and succinic acids are unstable at the operating temperature of the gas chromatograph. These acids were detected by prior preparation of their methyl esters which are stable and readily separate on the column. Freshly prepared diazomethane (de Boer and Backer, 1954) was used as the methylating agent, 2-3 drops being added to a portion of the extract.

Chromatographic conditions. Analyses were performed on a Pye 104 gas chromatograph, fitted with a flame-ionisation detector and a 5-ft glass column packed with "Diatomite C" that had been treated with phosphoric acid and impregnated with $10 \%$ polyethylene glycol. The operating temperature was $125^{\circ} \mathrm{C}$ and the carrier gas was oxygen-free $\mathrm{N}_{2}$ passing through at $30 \mathrm{ml}$ per min. A 1- $\mu 1$ aliquot of the sample for analysis was injected on to the column.

\section{Biochemical tests}

Liquid media for biochemical tests were distributed in 5-ml screw-capped bottles, and seeded with two drops of actively growing culture from Robertson's cooked meat 
medium. The tops of the bottles were loosened before incubation in an anaerobic jar containing an atmosphere of $30 \% \mathrm{CO}_{2}$ and $70 \% \mathrm{H}_{2}$.

Fermentation tests. The fermentation tests were modifications of those described by Cato et al. (1970); $0.5 \mathrm{~g}$ aesculin or $1.0 \mathrm{~g}$ of other test carbohydrates were added to a $100-\mathrm{ml}$ volume of basal medium containing $2.0 \mathrm{~g}$ peptone, $1.0 \mathrm{~g}$ yeast extract, $0.05 \mathrm{~g}$ cysteine hydrochloride, $0.03 \mathrm{~g}$ sodium formaldehyde sulphoxylate, $0.001 \mathrm{~g} \mathrm{CaCl}_{2}, 0.001 \mathrm{~g} \mathrm{MgSO}_{4}, 0.005 \mathrm{~g}$ $\mathrm{KH}_{2} \mathrm{PO}_{4}, 0.005 \mathrm{~g} \mathrm{~K}_{2} \mathrm{HPO}_{4}, 0.05 \mathrm{~g} \mathrm{NaHCO}_{3}$, and $0.01 \mathrm{~g} \mathrm{NaCl}$. The $p \mathrm{H}$ of the media was adjusted to $7 \cdot 1 \pm 0 \cdot 1$ before autoclaving at $115^{\circ} \mathrm{C}$ for $20 \mathrm{~min}$. Cultures were incubated anaerobically at $37^{\circ} \mathrm{C}$ for 3 days. The final $p \mathrm{H}$ of the media was estimated by the addition of two drops of bromocresol purple indicator (BDH) and noting the colour change.

Test for aesculin hydrolysis. Two or three drops of a $1 \%$ solution of ferric chloride were added to a 3-day culture in aesculin medium. A positive test was denoted by the development of a black colour.

Test for gelatin liquefaction. The test cultures were seeded into Robertson's cooked meat media, to which were added charcoal gelatin disks (Oxoid). The appearance of free charcoal particles in the medium, after incubation for 14 days at $37^{\circ} \mathrm{C}$ indicated liquefaction of the gelatin.

Tests for nitrate reduction and indole production. Nitrate, nitrite and indole were estimated by conventional procedures (Cowan and Steel, 1965) in cultures grown anaerobically for 72 hours in indole-nitrate medium (Baltimore Biological Laboratories, USA).

Growth in bile medium. The test cultures were seeded into Thioglycollate Broth (Oxoid) supplemented with $20 \%$ ox-bile (Oxoid) and $0 \cdot 1 \%$ deoxycholic acid. Stimulation or inhibition of growth was determined by comparison with a control of the same culture in thioglycollate broth. These tests were incubated aerobically.

\section{RESULTS}

Survival of the isolates

The isolates had been stored at $-50^{\circ} \mathrm{C}$ in Robertson's cooked meat medium with $10 \%$ glycerol for between 9 months and a year; $81.5 \%$ of organisms isolated from USA specimens and $96 \%$ of Japanese isolates were recovered after storage for 1 year.

\section{Identity of the isolates}

A total of 196 strains of non-sporing anaerobes were isolated from the faeces of 34 people on a mixed western diet in the USA, England and Scotland; 215 strains were isolated from the faeces of 45 people on carbohydrate-rich diets in Uganda, India and Japan.

In the present study the genus definitions and species characteristics published in the Anaerobe Laboratory Manual of Holdeman and Moore (1972) were employed; they are briefly recapitulated in tables II and III.

\section{Genera of non-sporing anaerobes}

All the isolates could be assigned to genera. The predominant groups of non-sporing strict anaerobes in faeces were found to be similar for all the populations studied; they fell into three main genera: Bacteroides, Bifidobacterium and Eubacterium. Minor components of the anaerobic flora consisted of fusobacteria, propionibacteria and lactobacilli. Although similar groups of organisms were isolated from all the faecal samples, with bacteroides 


\section{TABLE II}

Genera of non-sporing anaerobes cited in this paper (modified from Cato et al., 1970)

BACTEROIDES

Small Gram-negative rods, with rounded ends, typically exhibit bipolar staining. Bact. fragilis produces from glucose, acetic and succinic acids with or without propionic, isobutyric, butyric, isovaleric and fumaric acids.

\section{FUSOBACTERIUM}

Small, Gram-negative spindle-shaped rods. Butyric acid is the major product of glucose fermentation.

\section{F. fusiforme (nucleatum)}

Also produces small amounts of lactic, propionic and succinic acids.

\section{BIFIDOBACTERIUM}

Gram-positive, branching (bifid) rods with spatulate ends. Acetic and lactic acids (ratio $1+: 1$ ) are the major end-products of glucose metabolism. All strains of species in the genus Bifidobacterium make similar fermentation products.

\section{EUBACTERIUM} acids.

Small Gram-positive rods. Produce mixtures of acids from glucose, or no major

E. aerofaciens produces acetic, formic and lactic acids from glucose.

\section{PROPIONIBACTERIUM}

Gram-positive rods, typically diphtheroid. Propionic and acetic acids are the major volatile acids produced from glucose. All species of propionibacteria make similar fermentation products.

\section{LACTOBACILLUS}

Straight Gram-positive rods, typically in chains. Lactic acid is the sole major product from glucose.

TABLE III

Differentiation of species of the major faecal anaerobes (after Cato et al., 1970)

\begin{tabular}{|c|c|c|c|c|c|c|}
\hline \multirow[b]{2}{*}{ Test } & \multicolumn{6}{|c|}{ Reactions of the stated species* } \\
\hline & $\begin{array}{l}\text { Bacteroides } \\
\text { fragilis }\end{array}$ & $\begin{array}{c}\text { Bacteroides } \\
\text { melaninogenicus }\end{array}$ & $\begin{array}{c}\text { Bifido- } \\
\text { bacterium } \\
\text { adolescentis }\end{array}$ & $\begin{array}{c}\text { Bifido- } \\
\text { bacterium } \\
\text { bifidum }\end{array}$ & $\begin{array}{c}\text { Bifido- } \\
\text { bacterium } \\
\text { eriksonii }\end{array}$ & $\begin{array}{c}\text { Eubacterium } \\
\text { aerofaciens }\end{array}$ \\
\hline Gelatinase & - & + & $\mathbf{w}^{-}$ & $-w$ & $-w$ & $w^{-}$ \\
\hline $\begin{array}{l}\text { Indole production } \\
\text { Acid from: }\end{array}$ & $\mathbf{v}$ & $\mathbf{v}$ & - & - & - & - \\
\hline glucose & + & $\mathbf{v}$ & + & + & + & + \\
\hline lactose & + & $\mathrm{v}$ & + & + & + & +- \\
\hline sucrose & + & $\mathbf{v}$ & + & - & + & +- \\
\hline maltose & + & $\mathbf{v}$ & + & - & + & + \\
\hline fructose & + & $\mathbf{v}$ & + & + & + & + \\
\hline mannose & + & $\mathbf{v}$ & +- & $-{ }^{w}$ & + & + \\
\hline mannitol & $\overline{-}$ & - & $\mathbf{v}$ & - & + & $\mathbf{v}$ \\
\hline arabinose & $\mathrm{v}$ & $\mathbf{v}$ & + & - & - & $\mathbf{v}$ \\
\hline xylose & + & $\mathbf{w}$ & + & $-w$ & + & -+ \\
\hline Aesculin hydrolysis & + & $\mathbf{v}$ & + & $-w$ & $\mathbf{v}$ & $+^{-}$ \\
\hline Nitrate reduction & -+ & - & - & - & - & -+ \\
\hline
\end{tabular}

$*+=$ positive reaction for $90-100 \%$ of strains; $-=$ negative reaction for $90-100 \%$ of strains; $w=w e a k$ reaction; $v=$ variable among strains; superscripts indicate reactions of occasional strains. 
TABle IV

Percentage frequency of genera of non-sporing anaerobes among isolates from faeces of populations consuming different diets

\begin{tabular}{|c|c|c|c|c|c|c|c|}
\hline \multirow{2}{*}{$\begin{array}{l}\text { Category of diet* and } \\
\text { populations sampled }\end{array}$} & \multirow{2}{*}{$\begin{array}{l}\text { Number of } \\
\text { isolates identified }\end{array}$} & \multicolumn{6}{|c|}{ Percentage frequency among isolates from the stated populations of genus } \\
\hline & & Bacteroides & Fusobacterium & Bifidobacterium & Eubacterium & Propionibacterium & Lactobacillus \\
\hline $\begin{array}{l}\text { "Mixed-western"; USA, } \\
\text { England, Scotland }\end{array}$ & 224 & $61 \cdot 6$ & 0.9 & $25 \cdot 0$ & $6 \cdot 7$ & $3 \cdot 1$ & $\mathbf{0}$ \\
\hline $\begin{array}{l}\text { “ High-carbohydrate”; } \\
\text { Uganda, India, Japan }\end{array}$ & 215 & $37 \cdot 7$ & $1 \cdot 4$ & $27 \cdot 0$ & $23 \cdot 2$ & $5 \cdot 1$ & 1.4 \\
\hline
\end{tabular}

* See table I. 
the most common isolates, there were differences in the distribution and relative proportions of these organisms. Faeces from " western-diet" countries (England, USA and Scotland) appeared to have a larger proportion of Gramnegative organisms (Bacteroides spp. and fusobacteria), than did those from people from countries with " high-carbohydrate diets" (India, Uganda and Japan). The consequently larger proportion of Gram-positive organisms found in faeces from these countries seemed to be due mainly to the contribution of the eubacteria (table IV); this increase in the proportion of eubacteria was statistically significant $(p=<0 \cdot 001)$. Propionibacteria were found in both of the population groups studied. Strictly anaerobic lactobacilli, however, were found only in faeces from Uganda and Japan.

TABLE V

Major species of non-sporing anaerobes found in faeces

\begin{tabular}{l|cc}
\hline & $\overbrace{\begin{array}{c}\text { USA, England } \\
\text { or Scotland }\end{array}}^{\begin{array}{c}\text { Percentage number of isolates classified as } \\
\text { stated and country of origin of the samples }\end{array}}$ \\
\hline $\begin{array}{l}\text { Uganda, India } \\
\text { or Japan }\end{array}$ \\
Organisms identified at species level & 88.5 & 85 \\
Bacteroides spp. found to be Bact. fragilis & 92 & 98 \\
$\begin{array}{l}\text { Bifidobacterium spp. found to be: } \\
\begin{array}{l}\text { Bi. adolescentis } \\
\text { Bi. bifidum }\end{array}\end{array}$ & 59 & 63.5 \\
$\begin{array}{l}\text { Bi. eriksonii } \\
\text { Eubacterium spp. found to be E. aerofaciens }\end{array}$ & $\begin{array}{l}53 \\
10.0\end{array}$ \\
\hline
\end{tabular}

\section{Sub-division of major genera}

More than $80 \%$ of the isolates could be assigned to species, and the same major species of non-sporing anaerobes were found in faeces from all the dietary groups.

Almost all the bacteroides organisms were identified as Bact. fragilis (table V). Two-thirds of the bifidobacteria were identified as Bi. adolescentis; Bi. bifidum and $\mathrm{Bi}$. eriksonii were also common. However, $8 \%$ of bifidobacteria from "western-diet " countries and $14 \%$ from " high-carbohydrate-diet " countries, could not be assigned to any species. More than $80 \%$ of the eubacteria could be shown to be $E$. aerofaciens.

\section{Minor species of non-sporing anaerobes}

A variety of minor species of non-sporing strict anaerobes were isolated and identified (table VI). The isolation of Bact. melaninogenicus from human faeces is not unusual, but other, more unexpected, bacteroides species were also found (see Discussion). 
TABLE VI

Minor species of non-sporing anaerobes isolated from faeces in the present study

\begin{tabular}{|c|c|c|}
\hline Species & $\begin{array}{l}\text { Number of times } \\
\text { isolated }\end{array}$ & Source \\
\hline $\begin{array}{l}\text { Bacteroides melaninogenicus } \\
\text { Bact. hypermegas } \\
\text { Bact. ruminicola } \\
\text { Bact. trichoides } \\
\text { Bact. oralis }\end{array}$ & $\begin{array}{l}5 \\
1 \\
1 \\
1 \\
1\end{array}$ & $\begin{array}{l}\text { USA and India } \\
\text { India } \\
\text { Japan } \\
\text { Japan } \\
\text { Japan }\end{array}$ \\
\hline $\begin{array}{l}\text { Fusobacterium fusiforme (nucleatum) } \\
\text { F. plauti } \\
\text { F.abscendens }\end{array}$ & $\begin{array}{l}3 \\
2 \\
1\end{array}$ & $\begin{array}{l}\text { Japan } \\
\text { Japan } \\
\text { Japan }\end{array}$ \\
\hline $\begin{array}{l}\text { Eubacterium lentum } \\
\text { E. tortuosum } \\
\text { E. limosum } \\
\text { E. ventriosum } \\
\text { E. contortum }\end{array}$ & $\begin{array}{l}9 \\
4 \\
4 \\
1 \\
2\end{array}$ & $\begin{array}{l}\text { Scotland and India } \\
\text { Japan } \\
\text { Japan } \\
\text { Japan } \\
\text { Japan }\end{array}$ \\
\hline $\begin{array}{l}\text { Propionibacterium acnes } \\
P . \text { avidum } \\
P . \text { jensenii } \\
P . \text { freundreichii } \\
P . \text { theonii }\end{array}$ & $\begin{array}{r}11 \\
9 \\
5 \\
3 \\
1\end{array}$ & $\begin{array}{l}\text { Scotland, USA, India } \\
\text { England, USA, India and Japan } \\
\text { India and Japan } \\
\text { USA and Japan } \\
\text { Japan }\end{array}$ \\
\hline $\begin{array}{l}\text { Lactobacillus catenaforme } \\
\text { L. crispatus }\end{array}$ & $\begin{array}{l}4 \\
1\end{array}$ & $\begin{array}{l}\text { Japan and Uganda } \\
\text { Japan }\end{array}$ \\
\hline
\end{tabular}

\section{Discussion}

The complete characterisation of the bacterial flora of the intestine is not yet possible. Many previous studies of the faecal flora have concentrated upon the aerobic component of the flora. While the numerical dominance of the non-sporing anaerobes in faeces is well established (Eggerth and Gagnon, 1933) little is known about the factors controlling them.

In the present study several unexpected species of anaerobe were isolated. Bact. hypermegas is common in the intestine of poultry, and Bact. ruminicola in the bovine rumen. Bact. trichoides is common in the intestine of pigs. Bact. oralis is frequently isolated from the human mouth and is similar to Bact. fragilis. Fusobacterium fusiforme is also found in the mouth, and organisms of this species that we recovered from faeces were probably passed down the intestinal tract with food. All the species of eubacteria isolated are common intestinal organisms (Holdeman and Moore, 1972). It is possible that Propionibacterium acnes and $P$. avidum were contaminants derived from the skin of the perianal area, skin being the more common habitat of these organisms. $P$. jensenii, $P$. freundreichii and $P$. theonii have not in the past been thought of as predominantly intestinal organisms, more usually being isolated from dairy products. Their isolation from faeces is interesting; some were isolated in the present study from persons whose diet would not have included much dairy produce. It is probable that the strictly anaerobic 
Lactobacillus catenaforme is truly a human intestinal organism. L. crispatus is common in the gastro-intestinal tract of cows and pigs.

Studies by Moore and Holdeman (1972) with 1057 isolates from six faecal specimens have demonstrated the presence of 86 species of anaerobe and undoubtedly many more would be found if a greater number of isolates could be characterised. Our main interest in the present study was in the comparison of dietary groups rather than the exhaustive study of individuals. The study demonstrates the predominance of eubacteria in people on a carbohydrate-rich diet. However, the groups studied differ in many respects other than diet, so to assign a controlling role to this factor is probably not justified. Indeed,

TABLE VII

An analysis of the predominant bacterial groups in faeces sampled from subjects on different diets in Japan and the USA

\begin{tabular}{|c|c|c|c|c|c|c|}
\hline \multirow{2}{*}{$\begin{array}{l}\text { Number of } \\
\text { individuals }\end{array}$} & \multirow{2}{*}{ Diet* } & \multirow{2}{*}{$\begin{array}{l}\text { Country } \\
\text { of origin }\end{array}$} & \multicolumn{4}{|c|}{$\begin{array}{l}\text { Percentage occurrence of organisms of the } \\
\text { stated group as the predominant component } \\
\text { of the faecal flora }\end{array}$} \\
\hline & & & $\begin{array}{l}\text { Bacteroides } \\
\text { spp. }\end{array}$ & $\begin{array}{l}\text { Bifido- } \\
\text { bacteria }\end{array}$ & Eubacteria & Mixed \\
\hline 21 & "High carbohydrate" & Japan & 38 & 19 & $9 \cdot 5$ & $33 \cdot 5$ \\
\hline 24 & "Mixed western" & USA & 46 & 21 & $\ldots$ & 33 \\
\hline
\end{tabular}

* See table I.

consideration of the data from individuals in this study indicates that the difference between the groups might be accounted for on the basis of the different dominant organisms in various individuals (table VII). This contention is supported by the finding of Moore et al. (1969) that the flora was very little influenced by dietary manipulation and the dominant bacterial species in the intestine of an individual tended to remain constant for long periods. The mechanisms by which a particular bacterial species is selected for dominance in an individual are unknown, but presumably host factors are very important and diet may act indirectly through its influence on the host rather than directly on the flora.

\section{SUMMARY}

Non-sporing strictly anaerobic bacteria were isolated from human faecal samples from England, Scotland, USA, India, Uganda and Japan. Strains were assigned to genera on the basis of the Gram reaction and on the type of fatty acid produced from glucose. Analysis of these acids was by gas-liquid chromatography. The isolates were further classified on the basis of various biochemical reactions.

Bacteroides fragilis was the non-sporing anaerobe most frequently isolated from human faeces. Bifidobacterium adolescentis and Eubacterium aerofaciens 
were also frequently isolated. Stool samples from India, Uganda and Japan contained a larger proportion of eubacteria and fewer Bacteroides spp. than did the samples from England, Scotland and the USA.

This project was supported financially by the Cancer Research Campaign. B. S. D. would like to acknowledge support from the Wellcome Trust.

\section{REFERENCES}

Aranki, A., Syed, S. A., Kenney, E. B. ANd Fretter, R. 1969. Isolation of anaerobic bacteria from human gingiva and mouse cecum by means of a simplified glove-box procedure. Appl. Microbiol., 17, 568.

Cato, E. P., Cummins, C. S., Holdeman, L. V., Johnson, J. L., Moore, W. E. C., Smibert, R. M. AND SMITH, L. DS. 1970. In Outline of clinical methods in anaerobic bacteriology, 2nd revision, Blacksburg, Virginia.

Cowan, S. T. ANd Steel, K. J. 1965. Manual for the identification of medical bacteria, London.

CROWTHER, J. S. 1971. Transport and storage of faeces for bacteriological examination. J. appl. Bact., 34, 477.

DE BOER, T. J. AND BACKER, H. J. 1954. A new method for the preparation of diazomethane. Recl. Trav. Chim. Pays-Bas Belg., 73, 229.

Drasar, B. S. 1967. Cultivation of anaerobic intestinal bacteria. J. Path. Bact., 94, 417.

DUDGEON, L. S. 1926. A study of the intestinal flora under normal and abnormal conditions. J. Hyg., Camb., 25, 119.

Eggerth, A. H. and GaGnon, B. H. 1933. The bacteroides of human faeces. J. Bact., $25,389$.

Hill, M. J., Crowther, J. S., Drasar, B. S., Hawksworth, G., Aries, V. and Williams, R. E. O. 1971. Bacteria and aetiology of cancer of the large bowel. Lancet, 1, 95.

Holdeman, L. V. AND Moore, W. E. C. 1972. (Editors) Anaerobe laboratory manual, Blacksburg, Virginia.

Moore, W. E. C. and Holdeman, L. V. 1972. Identification of anaerobic bacteria. Am. J. clin. Nutr., 25, 1306.

Moore, W. E. C., Cato, E. P. and Holdeman, L. V. 1969. Anaerobic bacteria of the gastro-intestinal flora and their occurrence in clinical infections. J. infect. Dis., 119, 641.

Preston, N. W. ANd Morrell, A. 1962. Reproducible results with the Gram stain. $J$. Path. Bact., 84, 241.

SMirt, H. W. 1965. Observations on the flora of the alimentary tract of animals and factors affecting its composition. J. Path. Bact., 89, 95. 